\title{
Iron(II)oxalate Dihydrate-Humboldtine: Synthesis, Spectroscopic and Structural Properties of a Versatile Precursor for High Pressure Research
}

\author{
Harald Müller*iD, Léa Bourcet and Michael Hanfland (CD \\ ESRF-The European Synchrotron, CS 43220 CEDEX 9, F-38000 Grenoble, France; \\ bourcet@esrf.fr (L.B.); hanfland@esrf.fr (M.H.) \\ * Correspondence: mueller@esrf.fr
}

check for updates

Citation: Müller, H.; Bourcet, L.; Hanfland, M. Iron(II)oxalate Dihydrate-Humboldtine: Synthesis, Spectroscopic and Structural Properties of a Versatile Precursor for High Pressure Research. Minerals 2021, 11, 113. https://doi.org/10.3390/min 11020113

Academic Editor: Patrizia Fumagalli Received: 22 December 2020

Accepted: 18 January 2021

Published: 23 January 2021

Publisher's Note: MDPI stays neutral with regard to jurisdictional claims in published maps and institutional affiliations.

Copyright: (C) 2021 by the authors. Licensee MDPI, Basel, Switzerland. This article is an open access article distributed under the terms and conditions of the Creative Commons Attribution (CC BY) license (https:/ / creativecommons.org/licenses/by/ $4.0 /)$.

\begin{abstract}
Iron(II)oxalate dihydrate $\mathrm{FeC}_{2} \mathrm{O}_{4} \times 2 \mathrm{H}_{2} \mathrm{O}$ - humboldtine is not only an important synthetic intermediate, but also a key building block for the preparation of various advanced materials. Interestingly, $\mathrm{FeC}_{2} \mathrm{O}_{4} \times 2 \mathrm{H}_{2} \mathrm{O}$ can be transformed readily into phase-pure siderite $\mathrm{FeCO}_{3}$. The importance of siderite for earth sciences, in particular for the understanding of the deep carbon cycle of our planet, is paramount. The availability of high-quality single crystals of $\mathrm{FeC}_{2} \mathrm{O}_{4} \times 2 \mathrm{H}_{2} \mathrm{O}$ is crucial for diffraction or spectroscopic studies at high pressure. The present article describes a versatile synthetic approach to single crystals of $\mathrm{FeC}_{2} \mathrm{O}_{4} \times 2 \mathrm{H}_{2} \mathrm{O}$ and its deuterated analogue starting from metallic iron together with a complete characterization of the products obtained. The same protocol has been employed successfully for the preparation of ${ }^{57} \mathrm{FeC}_{2} \mathrm{O}_{4} \times 2 \mathrm{H}_{2} \mathrm{O}$, as required for Mößbauer spectroscopy. In addition, the pressure-dependence of the crystal and molecular structure of the title compound was investigated up to $p \geq 20 \mathrm{GPa}$.
\end{abstract}

Keywords: iron(II)oxalate dihydrate $\mathrm{FeC}_{2} \mathrm{O}_{4} \times 2 \mathrm{H}_{2} \mathrm{O}$; iron(II)oxalate dideuterate $\mathrm{FeC}_{2} \mathrm{O}_{4} \times 2 \mathrm{D}_{2} \mathrm{O}$; ${ }^{57} \mathrm{FeC}_{2} \mathrm{O}_{4} \times 2 \mathrm{H}_{2} \mathrm{O}$; humboldtine; hydrothermal synthesis; single crystal diffraction; high pressure

\section{Introduction}

Iron(II)oxalate dihydrate $\mathrm{FeC}_{2} \mathrm{O}_{4} \times 2 \mathrm{H}_{2} \mathrm{O}$ is the ferrous salt of ethandicarboxylic acid (oxalic acid). The corresponding, naturally occurring mineral is known as humboldtine and has been described first almost 200 years ago [1]. Humboldtine is a rare mineral often associated with coal deposits but may also form by the interaction of fungi and iron-bearing rocks [2]. Iron(II)oxalate dihydrate decomposes easily upon heating $[3,4]$. This thermal instability has been employed widely for the preparation of various iron oxides [5-7].

$\mathrm{FeC}_{2} \mathrm{O}_{4} \times 2 \mathrm{H}_{2} \mathrm{O}$ has emerged as an important building block for the preparation of new, functional advanced materials. In this context, high, thermally activated proton conductivity of synthetic humboldtine has been reported [8]. In addition, iron(II)oxalate dihydrate displays remarkable photocatalytic properties [9]. Anhydrous iron oxalates have been used extensively as promising anode materials for Li-ion batteries [10,11].

While an impressive body of information is available on the thermal, spectroscopic, magnetic, and structural properties of iron(II)oxalate dihydrate at ambient conditions, little if anything is known about the pressure-dependence of the molecular and crystal structure [3-19].

Synthetic humboldtine is of considerable interest for earth sciences in that it can be used as precursor for the preparation of phase-pure iron(II)carbonate $\mathrm{FeCO}_{3}$ [20-22]. The latter is the synthetic equivalent of the mineral siderite, which may act as carbon carrier and as carbon-host in geochemical reservoirs in the interior of the earth $[23,24]$. Most naturally occurring siderites are iron-rich end members of a solid solution series $\mathrm{Mg}_{1-\mathrm{x}} \mathrm{Fe}_{\mathrm{x}} \mathrm{CO}_{3}$, composed essentially of the minerals siderite and magnesite $\mathrm{MgCO}_{3}$ together with other carbonates such as manganese(II)carbonate, rhodochrosite, $\mathrm{MnCO}_{3}$, or calcite; siderite 
with ideal stoichiometric composition is unknown in nature [25-27]. Hence, investigations aiming at a better understanding of the role of iron(II)carbonate in the deep carbon cycle depend on a reliable source of phase-pure, synthetic siderite [21,22,24].

Owing to its poor solubility, the reaction of a ferrous salt with oxalic acid or watersoluble oxalates in aqueous solution yields iron(II)oxalate, albeit only as microcrystalline powder. The precipitate can be used without further purification [4,28], hence the synthesis of the title compound is considered as being straightforward. Iron(II)oxalate powder is a commercial compound.

The preparation of single crystals of humboldtine suitable for X-ray diffraction or ${ }^{57} \mathrm{Fe}$ Möß $\beta$ bauer spectroscopy at ambient and elevated pressures is more demanding and requires the use of inert gas and hydrothermal synthesis technique [19]. The syntheses of many simple salts of divalent iron have been described in the literature [29], while a detailed protocol for the preparation of iron(II)oxalate dihydrate has been lacking to date.

In the literature, the Greek prefix $\alpha$ denotes ordered $\mathrm{FeC}_{2} \mathrm{O}_{4} \times 2 \mathrm{H}_{2} \mathrm{O}$ or humboldtine, while the prefix $\beta$ refers to polymorphic solids displaying crystallographic disorder [16].

Hereafter, $\mathrm{FeC}_{2} \mathrm{O}_{4} \times 2 \mathrm{H}_{2} \mathrm{O}$ or humboldtine always refer to $\alpha-\mathrm{FeC}_{2} \mathrm{O}_{4} \times 2 \mathrm{H}_{2} \mathrm{O}$, the three terms are used as synonyms.

Here, we present a versatile synthetic approach to single crystals of iron(II)oxalate dihydrate $\mathrm{FeC}_{2} \mathrm{O}_{4} \times 2 \mathrm{H}_{2} \mathrm{O}$, iron(II)oxalate dideuterate $\mathrm{FeC}_{2} \mathrm{O}_{4} \times 2 \mathrm{D}_{2} \mathrm{O}$, and isotopically labelled ${ }^{57} \mathrm{FeC}_{2} \mathrm{O}_{4} \times 2 \mathrm{H}_{2} \mathrm{O}$ starting from metallic iron as precursor and provide a complete characterization of the products obtained. Moreover, the pressure dependence of the crystal and molecular structure of the title compound is reported for applied hydrostatic pressures up to $p \geq 20 \mathrm{GPa}$.

\section{Materials and Methods}

\subsection{Chemicals and Instrumentation}

All experiments were carried out in inert atmosphere (Ar) using Schlenk techniques. Degassed water and degassed, dilute sulphuric acid were prepared by bubbling $\operatorname{Ar}(30 \mathrm{~min})$ through the reagents in a washing bottle equipped with a Drechsel insert.

Commercial dimethyl oxalate was used as received. For the deuteration experiments sulphuric acid- $\mathrm{d}_{2}$ solution in $\mathrm{D}_{2} \mathrm{O}(99.5 \% \mathrm{D})$ and deuterium oxide $(99 \% \mathrm{D})$ were used. ${ }^{57} \mathrm{Fe}$ (isotope abundances: ${ }^{57} \mathrm{Fe}, 95.06 \% ;{ }^{58} \mathrm{Fe}, 1.86 \% ;{ }^{56} \mathrm{Fe}, 3.04 \% ;{ }^{54} \mathrm{Fe}, 0.04 \%$ ) was purchased from Chemotrade $\mathrm{GmbH}$, Germany.

Hydrothermal reactions were carried out in Teflon-lined stainless steel sample preparation bombs (model 4749) from Parr Instruments.

FT-IR spectra were recorded on a Bruker Vertex 70 spectrometer either as $\mathrm{KBr}$ pellets or with a Bruker Platinium ATR device (Bruker, Marne-La Vallée, France). UV/VIS solid state reflectance spectra were recorded on a Shimadzu 3600 UV/VIS/NIR spectrophotometer (Shimadzu, Kyoto, Japan) equipped with an integration sphere as dispersions in $\mathrm{BaSO}_{4}$.

\subsection{Preparation of Single Crystals of $\mathrm{Fe}\left(\mathrm{C}_{2} \mathrm{O}_{4}\right) \times 2 \mathrm{H}_{2} \mathrm{O}$}

Step 1: Iron (filings; $100 \mathrm{mg} ; 1.79 \times 10^{-3} \mathrm{~mol}$ ) was transferred into a two-neck round bottom flask $(25 \mathrm{~mL})$ attached to a condenser. Dilute, degassed, aqueous sulphuric acid $\left(1 \mathrm{M}, 5.5 \mathrm{~mL} ; 5.5 \times 10^{-3} \mathrm{~mol}\right)$ was added with stirring via syringe/septum. An excess of sulphuric acid is indispensable to dissolve iron. Even with a threefold excess of acid, dissolution was inncomplete. The resulting reaction mixture (slurry) was stirred with heating $\left(1 \mathrm{~h} ; 40^{\circ} \mathrm{C}\right)$ and transformed slowly with hydrogen evolution into a transparent, grey-green solution, which still contained unreacted iron filings. After cooling to ambient temperature (ice-bath), the reaction mixture was filtered through a hydrophilic syringe filter (por. $0.2 \mu \mathrm{m}$ ) into a round bottom Schlenk flask equipped with a rubber septum. The two-neck round bottom flask was rinsed thoroughly with degassed water $(6 \mathrm{~mL})$, the rinsings were transferred via syringe filtration into the Schlenk flask with the iron(II) sulphate solution. 
Step 2: Dimethyl oxalate $\left(254 \mathrm{mg} ; 2.15 \times 10^{-3} \mathrm{~mol}\right)$ was transferred into a Teflon-lined stainless-steel mineralization bomb (Parr; $23 \mathrm{~mL}$ ). Dimethyl oxalate has to be used in excess to achieve complete precipitation. The bomb with dimethyl oxalate and the Schlenk flask containing the previously prepared aqueous $\mathrm{FeSO}_{4}$ solution was loaded into a glove-bag, which was then evacuated and carefully refilled 10 times with $\mathrm{Ar}$ as inert gas. The bomb was mounted and closed. The reaction mixture was heated in a drying oven $\left(120^{\circ} \mathrm{C} / 24 \mathrm{~h}\right)$. After the end of the heating, the reaction mixture was allowed to cool slowly to ambient temperature. Quenching of the reaction vessel in an ice-water bath at the end of the reaction time did not influence the size and quality of the crystals. The product was collected on a Büchner funnel, rinsed with water until the washing-water was acid-free, and dried in vacuo over silica gel to give bright yellow crystals. Typical reaction conditions and yields are summarized in Table 1.

Table 1. Typical reaction conditions for the hydrothermal synthesis of single crystals of iron(II)oxalate dihydrate $\mathrm{FeC}_{2} \mathrm{O}_{4} \times 2 \mathrm{H}_{2} \mathrm{O}$, iron(II)oxalate dideuterate $\mathrm{FeC}_{2} \mathrm{O}_{4} \times 2 \mathrm{D}_{2} \mathrm{O}$, and isotopically labelled ${ }^{57} \mathrm{FeC}_{2} \mathrm{O}_{4} \times 2 \mathrm{H}_{2} \mathrm{O}$.

\begin{tabular}{cccc}
\hline Fe Reactant Mass (mg) & Reaction Time (h) ${ }^{\mathbf{1}}$ & Yield $(\mathbf{m g} / \%)^{2)}$ & Comment \\
\hline $50 \mathrm{mg}$ & 24 & $106 / 64$ & $/$ \\
$50 \mathrm{mg}$ & 24 & $125 / 78$ & $/$ \\
$50 \mathrm{mg}$ & 24 & $70 / 44$ & ${ }^{57} \mathrm{Fe}($ see above) \\
$100 \mathrm{mg}$ & 24 & $203 / 63$ & $\mathrm{D}_{2} \mathrm{O}$ and $\mathrm{D}_{2} \mathrm{SO}_{4}{ }^{3)}$ \\
$200 \mathrm{mg}$ & 24 & $286 / 45$ & $/ 3{ }^{3}$ \\
\hline
\end{tabular}

1) The reaction temperature was always $120{ }^{\circ} \mathrm{C}$ (air-bath). ${ }^{2)}$ All products obtained as $\alpha$-phase (vide infra)

3) Reaction vessel quenched in an ice-bath after indicated reaction time.

$$
\begin{aligned}
& \mathrm{FeC}_{2} \mathrm{O}_{6} \mathrm{H}_{4} \mathrm{~F} . W .: 179.89 \mathrm{~g} / \mathrm{mol} \\
& \mathrm{IR}(\mathrm{ATR}) \text { v: } 3304,1615,1357,1311,816,707,482(\mathrm{vs}) \mathrm{cm}^{-1} . \\
& \mathrm{FeC}_{2} \mathrm{O}_{6} \mathrm{D}_{4} \text { F.W.: } 183.91 \mathrm{~g} / \mathrm{mol} \\
& \text { IR(ATR) v: } 2486,2445,1615,1357,1311,802,707,482(\mathrm{vs}) \mathrm{cm}^{-1} .
\end{aligned}
$$

\subsection{High Pressure Studies}

Suitable single crystals were selected visually under a stereomicroscope and loaded in diamond anvil cells with large $\left(76^{\circ}\right)$ opening angles and a culet size of $600 \mu \mathrm{m}$. Stainless steel gaskets were indented to $80 \mu \mathrm{m}$, the initial sample-hole diameter was $300 \mu \mathrm{m}$. Helium was used as pressure transmitting medium to ensure quasi-hydrostatic pressure conditions. The pressure was measured with the ruby fluorescence method based on the nonlinear hydrostatic pressure scale developed by Mao et al. [30].

Single-crystal diffraction data were collected using the rotation method on the ID15B beamline of the ESRF [31]. The cell was rotated around the $\omega$-axis from $-38^{\circ}$ to $38^{\circ}$. 152 diffraction images with a step size of $0.5^{\circ}$ and an exposure time of $1 \mathrm{~s}$ collected for each dataset with a MAR555 flat panel detector. The detector-to-sample distance was $260 \mathrm{~mm}$. The beam size, focused by compound refractive lenses, was about $10 \times 10 \mu \mathrm{m}^{2}$. Further details are provided in Tables 3 and 4, respectively.

The single crystal data were indexed and integrated with CrysAlis ${ }^{\mathrm{PRO}}$ v.1.171.38.46 [32]. Structural models were refined with CRYSTALS v.12 [33]. In a first step, the structure was refined without hydrogen atoms. Iron, oxygen, and carbon atoms were refined with anisotropic temperature factors. After the hydrogen atoms were added via a Fourier search, a final refinement of the structure was performed, riding the hydrogen atoms. Adding the hydrogen atoms resulted in a significant amelioration of the R-values by about $0.5 \%$. The structural models were analyzed and visualized with VESTA [34]. Equation of state parameters were determined with EosFit [35].

In total, three different samples were studied, two single crystals of iron(II)oxalate dihydrate $\mathrm{FeC}_{2} \mathrm{O}_{4} \times 2 \mathrm{H}_{2} \mathrm{O}$, one of iron(II)oxalate dideuterate $\mathrm{FeC}_{2} \mathrm{O}_{4} \times 2 \mathrm{D}_{2} \mathrm{O}$, from ambient $\mathrm{p}$ up to a pressure well above $20 \mathrm{GPa}$. 


\section{Results}

\subsection{Synthesis}

In the literature, a plethora of experimental protocols aiming at the preparation of (isostructural) oxalates of divalent metal ions such as $\mathrm{Fe}^{2+}, \mathrm{Co}^{2+}, \mathrm{Zn}^{2+}$ and $\mathrm{Ni}^{2+}$ has been described [3,4,6,9-11,14-19].

Most, if not all synthetic approaches to $\mathrm{FeC}_{2} \mathrm{O}_{4} \times 2 \mathrm{H}_{2} \mathrm{O}$, are based on salt metathesis reactions. The aqueous solution of a suitable ferrous salt is combined with (usually an excess of) a solution of oxalic acid or a suitable oxalate. As ferrous oxalate is only sparingly soluble in water, precipitation occurs upon combination of the reactants, while the counterions remain in solution. The polycrystalline precipitate can be collected and used without further purification.

Depending on the reaction conditions employed, products with identical chemical composition, but distinct thermochemical behavior and X-ray powder diffraction patterns were obtained. Initially interpreted as presence of polymorphic phases, these observations reflect the propensity of divalent transition metal oxalates to form disordered crystalline solids. Crystallographic disorder of oxalates of divalent transition metals may result in considerable alterations of the physical properties and is usually the consequence of reactions carried out in thermodynamic disequilibrium [14-17].

The double displacement method is operationally simple but has several important disadvantages. This approach provides only microcrystalline powder and depends on the (commercial) availability of the precursors. Single crystals of the title compound cannot be prepared in that way but require hydrothermal synthesis conditions [19].

Particular care has to be taken to avoid the inadvertent formation and pollution of the product with trivalent iron $\mathrm{Fe}^{3+}$, particularly when stoichiometric amounts of reactants are being used. Iron(III)oxalate is a known, stable compound [36].

For the preparation of isotopically substituted derivatives as single crystals, it is indispensable to start from elemental iron, since the corresponding precursors are not commercially available.

Our preparative two-step approach starts with the dissolution of iron in dilute sulphuric acid and subsequent reaction of the obtained iron(II)sulphate solution with excess dimethyl oxalate under autogenous pressure according to Equations (1) and (2).

$$
\begin{gathered}
\mathrm{Fe}+\mathrm{H}_{2} \mathrm{SO}_{4}\left(\mathrm{H}_{2} \mathrm{SO}_{4}+\mathrm{H}_{2} \mathrm{O} \text { in excess }\right) \rightarrow \mathrm{Fe}^{2+}+\mathrm{SO}_{4}{ }^{2-}+\mathrm{H}_{2} \uparrow+\left(\mathrm{H}_{2} \mathrm{SO}_{4}+\mathrm{H}_{2} \mathrm{O} \text { in excess }\right) \\
\mathrm{Fe}^{2+}+\mathrm{SO}_{4}{ }^{2-}+\mathrm{HO}_{2} \mathrm{CCO}_{2} \mathrm{H}(\text { excess })+\left(\mathrm{H}_{2} \mathrm{SO}_{4}+\mathrm{H}_{2} \mathrm{O} \text { in excess }\right) \rightarrow \\
{\left[\mathrm{Fe}^{\mathrm{II}}\left(\mathrm{C}_{2} \mathrm{O}_{4}\right) \times 2 \mathrm{H}_{2} \mathrm{O}\right] \downarrow+\left(\mathrm{HO}_{2} \mathrm{CCO}_{2} \mathrm{H}+\mathrm{H}_{2} \mathrm{SO}_{4}+\mathrm{H}_{2} \mathrm{O} \text { in excess }\right)}
\end{gathered}
$$

For simplicity, dimethyl oxalate (DMO) has been replaced in Equation (2) with oxalic acid. The latter is released in situ upon heating of the reaction mixture. The use of adequate inert gas techniques to avoid oxidation of $\mathrm{Fe}^{2+}$ to $\mathrm{Fe}^{3+}$ is of utmost importance.

All reactions were carried out in thermodynamic equilibrium as reflected by the reaction conditions summarized in Table 1.

It deserves mentioning that the same approach can be used for an efficient deuteration.

Details of the preparation of single crystals of iron(II)oxalate dihyrate $\mathrm{FeC}_{2} \mathrm{O}_{4} \times 2 \mathrm{H}_{2} \mathrm{O}$, iron(II)oxalate dideuterate $\mathrm{FeC}_{2} \mathrm{O}_{4} \times 2 \mathrm{D}_{2} \mathrm{O}$ suitable for high resolution neutron diffraction, and isotopically labelled ${ }^{57} \mathrm{FeC}_{2} \mathrm{O}_{4} \times 2 \mathrm{H}_{2} \mathrm{O}$ for Mößbauer Spectroscopy are provided in Section 2.2.

Figure 1 displays the characteristic morphology of crystals of $\alpha-\mathrm{FeC}_{2} \mathrm{O}_{4} \times 2 \mathrm{H}_{2} \mathrm{O}$ obtained under hydrothermal conditions. 


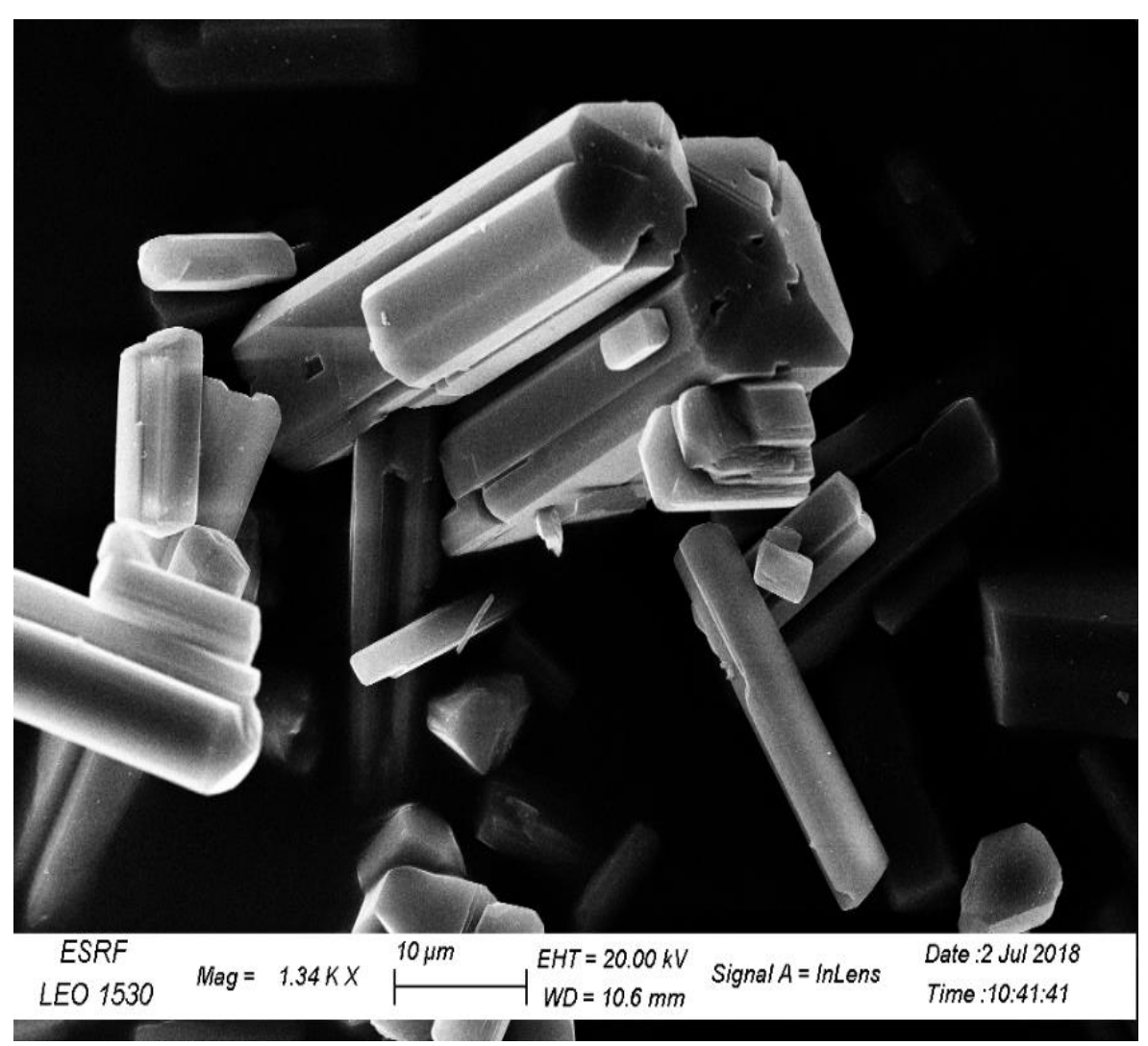

Figure 1. SEM-Micrograph of single crystals of $\alpha-\mathrm{FeC}_{2} \mathrm{O}_{4} \times 2 \mathrm{H}_{2} \mathrm{O}$.

\subsection{Spectroscopic Properties}

A typical UV/VIS/NIR solid-state reflectance spectrum of synthetic humboldtine is displayed in Figure 2. Contrary to the blueish-green appearance of many simple, divalent iron salts, microcrystalline $\mathrm{FeC}_{2} \mathrm{O}_{4} \times 2 \mathrm{H}_{2} \mathrm{O}$ is yellow-brownish, while single crystals are bright yellow. In accordance with the aspect of the solid, the spectrum exhibits an absorption below $250 \mathrm{~nm}$ followed by another shallow minimum at $330 \mathrm{~nm}$. These features might be caused by $\mathrm{n} \rightarrow \pi^{*}$ and $\pi \rightarrow \pi^{*}$ transitions of the resonance-stabilized carbonyl groups. In the absence of detailed spectroscopic investigations, such interpretation is merely speculation. Another shallow, broad absorption feature centered at around $1000 \mathrm{~nm}$ might be caused by electronic transitions of the $\mathrm{Fe}^{2+}$ cation in an octahedral crystal field, as observed for other iron(II) containing minerals. The overall appearance of the reflectance spectrum and the observed features are well in line with those reported in previous work $[9,37,38]$.

The FT-IR spectra of $\mathrm{FeC}_{2} \mathrm{O}_{4} \times 2 \mathrm{H}_{2} \mathrm{O}$ and its deuterated analogue are displayed in Figure 3. Both graphs exhibit the characteristic features expected for a simple metal oxalate $[39,40]$. The broad band at $3311 \mathrm{~cm}^{-1}$ can be assigned readily to the O-H stretch vibration of structurally coordinated water molecules. The vibrational fine structure reported earlier could not be observed $[19,40]$. The antisymmetric O-C-O stretch gives rise to another broad and intense signal at $1605 \mathrm{~cm}^{-1}$. The strong absorptions at 1361 and $1313 \mathrm{~cm}^{-1}$ are interpreted tentatively as symmetric elongation of the $\mathrm{O}-\mathrm{C}-\mathrm{O}$ bonds, whereas signals at 822 and $482 \mathrm{~cm}^{-1}$ could originate from C-C deformations and Fe-O stretch vibrations, respectively. A detailed, full analysis of the IR- and Raman-active vibrations of $\mathrm{FeC}_{2} \mathrm{O}_{4} \times 2 \mathrm{H}_{2} \mathrm{O}$ has been published [41].

As expected, upon deuteration, the position of the C-D stretch vibration of $\mathrm{FeC}_{2} \mathrm{O}_{4} \times 2 \mathrm{D}_{2} \mathrm{O}$ moves to higher energies thus giving rise to a broad signal centered at around $2450 \mathrm{~cm}^{-1}$. The observed splitting is indicative of additional bands and shoulders reported for the protonated analogue [40]. The other regions of the spectrum are 
only little affected by the replacement of $\mathrm{H}$ with $\mathrm{D}$. The O-D deformation appears as a low-intensity band at $1190 \mathrm{~cm}^{-1}$, whereas the corresponding signal of the protonated counterpart is buried under the O-C-O stretch. The absence of any signals originating from the presence of spurious water confirms a successful, quantitative $\mathrm{H} / \mathrm{D}$ exchange.

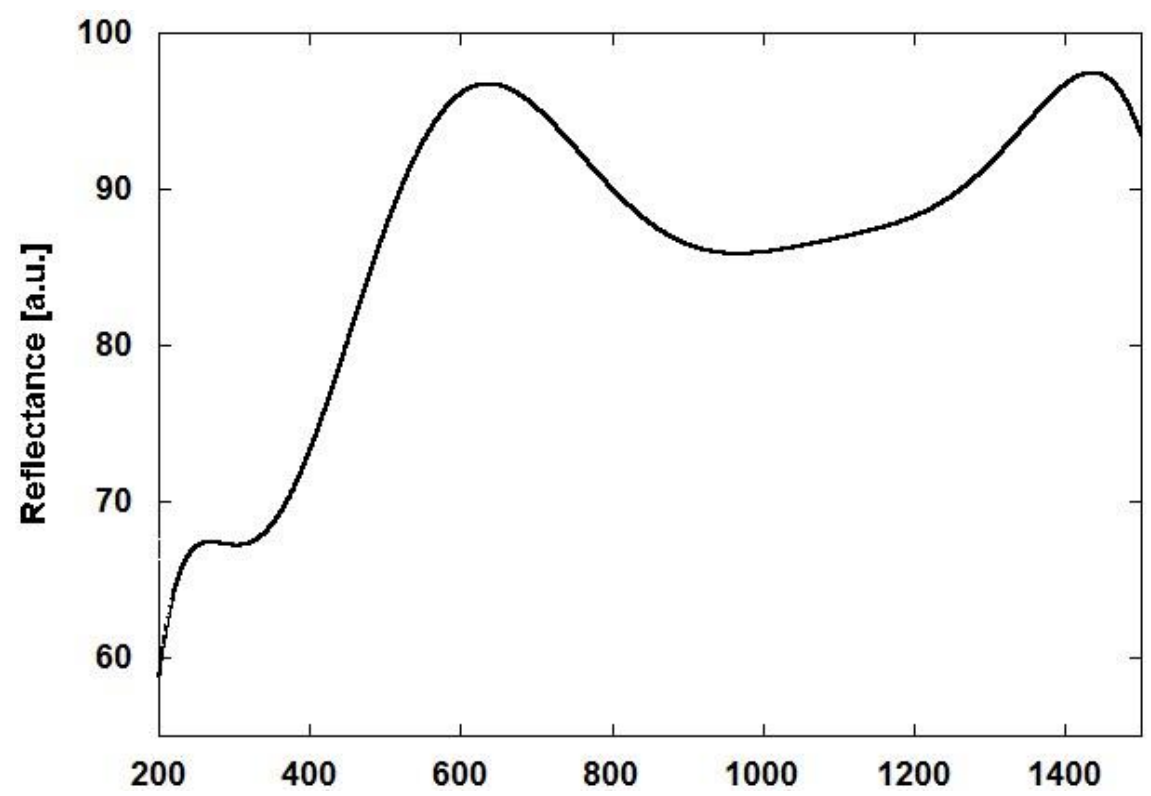

Figure 2. UV/VIS solid state reflectance spectrum of $\mathrm{FeC}_{2} \mathrm{O}_{4} \times 2 \mathrm{H}_{2} \mathrm{O}$.

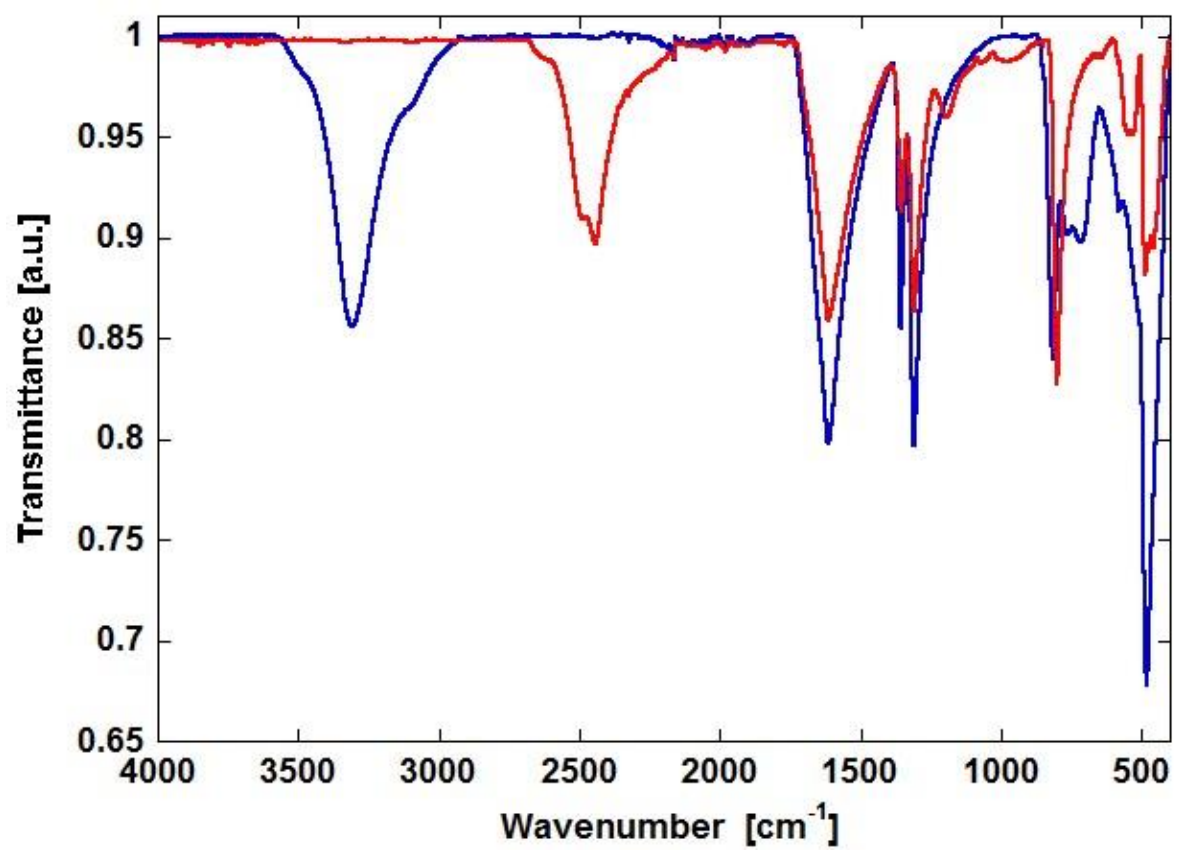

Figure 3. FT-IR Spectra of protonated $\mathrm{FeC}_{2} \mathrm{O}_{4} \times 2 \mathrm{H}_{2} \mathrm{O}$ (blue) and its deuterated analogue $\mathrm{FeC}_{2} \mathrm{O}_{4} \times 2 \mathrm{D}_{2} \mathrm{O}$ (red).

\subsection{Structural Properties}

In the present work, all synthetic operations were performed in thermodynamic equilibrium and gave only the stable a-polymorph as evidenced by single crystal X-ray diffraction. Lattice parameters and space groups are in excellent agreement with those reported in previous work [19]. The lattice parameters of synthetic humboldtine and its 
deuterated analogue studied in this work were practically identical and match well unit cell data obtained earlier by neutron powder diffraction [18].

Relevant crystallographic parameters are summarized in Table 2.

Table 2. Crystallographic parameters of $\alpha-\mathrm{FeC}_{2} \mathrm{O}_{4} \times 2 \mathrm{H}_{2} \mathrm{O}$ and $\beta-\mathrm{FeC}_{2} \mathrm{O}_{4} \times 2 \mathrm{H}_{2} \mathrm{O}$.

\begin{tabular}{|c|c|c|c|c|c|c|c|c|}
\hline Phase [Ref] & a [12]* & a [13] ** & a [14] ** & a [16] ** & $\beta[16]$ ** & $\beta[9]^{* *}$ & a [19] *** & This Work *** \\
\hline a $[\AA]$ & $12.04(3)$ & 12.060 & 11.99 & 12.05 & 12.26 & 12.2714 & $12.011(11)$ & $12.006(4)$ \\
\hline $\mathrm{b}[\AA]$ & $5.58(1)$ & 5.550 & 5.55 & 5.57 & 5.57 & 5.5372 & $5.557(5)$ & $5.55245(1)$ \\
\hline$c[\AA]$ & $9.89(2)$ & 9.804 & 9.89 & 9.76 & 15.48 & 15.5126 & $9.701(9)$ & $9.6970(2)$ \\
\hline $\mathrm{b}\left[{ }^{0}\right]$ & $127.34(4)$ & 127.58 & 128.3 & 124.18 & 90 & 90 & $126.924(3)$ & $126.900(4)$ \\
\hline$V\left[\AA^{3}\right]$ & 528.26 & 520.49 & 516.48 & 520.94 & 1053 & 1054.21 & $518.0(8)$ & 516.91(19) \\
\hline Space group & $\mathrm{C} 2 / \mathrm{c}$ & / & / & / & Cccm & Cccm & $\mathrm{C} 2 / \mathrm{c}$ & $\mathrm{C} 2 / \mathrm{c}$ \\
\hline
\end{tabular}

${ }^{*}$ determined by Weissenberg technique. ${ }^{* *}$ Cell parameters determined by powder diffraction. ${ }^{* * *}$ Cell determined at ambient conditions by $\mathrm{X}$-ray single crystal diffraction. The lattice parameters given in ref [19] were transformed to a standard setting (transformation: $-a,-b, a+c)$.

$\alpha-\mathrm{FeC}_{2} \mathrm{O}_{4} \times 2 \mathrm{H}_{2} \mathrm{O}$ may be viewed as a polymeric coordination compound or polymeric chelate-complex composed of bidentate oxalate dianions (ox) $\mathrm{C}_{2} \mathrm{O}_{4}{ }^{2-}$, divalent ferrous $\mathrm{Fe}^{2+}$ ions, and water molecules. The alternating planar arrangement of oxalate dianions and $\mathrm{Fe}^{2+}$ cations result in one-dimensional infinite linear chains ... oxFeoxFeox $\ldots$ along the $b$-axis as shown in Figure 4. The octahedral coordination sphere of each $\mathrm{Fe}^{2+}$-ion comprises four oxygen atoms of two oxalate dianions on equatorial positions and is completed by the oxygen atoms of two water molecules on axial positions approximately parallel to $a$ as shown in Figure 5. Water is thus an integral part of the crystal structure. The angle $\mathrm{H}_{2} \mathrm{O}-\mathrm{Fe}-\mathrm{OH}_{2}$ defined by the axial oxygen atoms and the central iron atom deviates slightly from linearity $\left(182^{\circ}\right.$ at ambient p; Figure 9$)$. The $\mathrm{H}_{2} \mathrm{O}$ molecules dispose of lone electron pairs, can act as electron donors, and form coordinate covalent bonds provoking in turn slightly oblique attachments relative to the polymeric chains. The three-dimensional structure of $\mathrm{FeC}_{2} \mathrm{O}_{4} \times 2 \mathrm{H}_{2} \mathrm{O}$ consists of linear infinite chains along [010], neighbouring chains in the $b$-c-plane are linked by hydrogen bonds between the oxygen atoms of water molecules and oxalate dianions belonging to adjacent chains as shown in Figure 5.

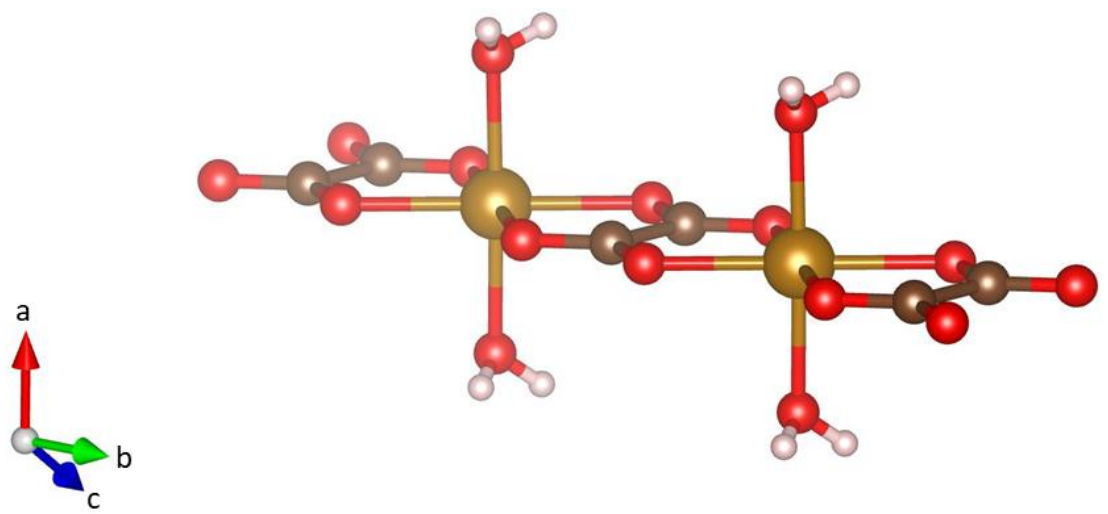

Figure 4. Representation of the single, infinite, planar 1-D chain of $\alpha-\mathrm{FeC}_{2} \mathrm{O}_{4} \times 2 \mathrm{H}_{2} \mathrm{O}$ with repetitive units composed of a divalent iron(II)cation, a bidentate oxalate dianion, and two water molecules. Iron atoms are bronze, oxygen atoms are red, carbon atoms are brown, and hydrogen atoms are white (top). 


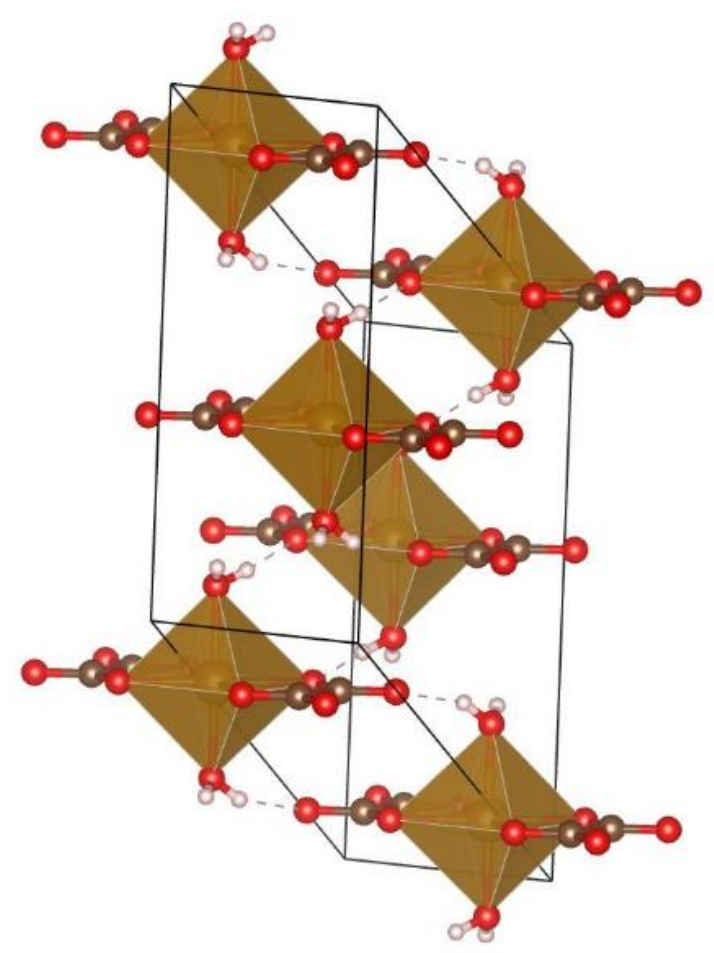

Figure 5. The slight distortion of the octahedral coordination sphere of the central iron(II)cations results from the presence of six oxygen atoms around the central iron ions: The oxygen atoms of two water ligands are in axial positions while four oxygen atoms of two bidentate oxalate dianions occupy equatorial positions. Alternating layers are connected through hydrogen bonds shown as dashed lines. Iron atoms are located in the center of the brown, shaded octahedron, oxygen atoms are displayed as red, carbon atoms as brown, and hydrogen atoms as white spheres.

Compression of iron(II)oxalate dihydrate was performed up $20 \mathrm{GPa}$ with He as pressure transmission medium. Refined structural models for iron(II)oxalate dihydrate at pressures of 0.1 and 16.7 GPa are shown in Figure 6a,b, respectively. Refinement details and structural parameters are given in Tables 3 and 4. Low R-values of 0.034 and 0.023 , respectively, demonstrate the excellent agreement of measured data and models, which improved even at high pressure.

The pressure dependence of the unit cell volume and the lattice parameters are shown in Figures 7 and 8, respectively. The large volume change from $719 \AA^{3}$ at ambient pressure to around $360 \AA^{3}$ at $p \leq 20 \mathrm{GPa}$ reflects the high compressibility along the $a$-and $c$-axes, while the $b$-axis shows a much lower, almost linear pressure dependence.

The monoclinic angle $\beta$ decreases rapidly from $127^{\circ}$ to $122^{\circ}$ up to $p \approx 5 \mathrm{GPa}$ but remains almost constant up to around $p \approx 20 \mathrm{GPa}$. At $p \approx 20 \mathrm{GPa}$, the title compound undergoes eventually a reversible structural phase transition, accompanied by a volume reduction of about $3.5 \%$.

The phase transition had a detrimental effect on the quality of the single crystal diffraction patterns and frustrated to date all attempts to determine a reliable structural model for the high pressure (HP) phase present at $p \geq 20 \mathrm{GPa}$.

As pressure increases oxalate chains approach each other and the hydrogen $\mathrm{H}$... O bond distances between neighboring chains shorten from approximately $2.0 \AA$ at $0.1 \mathrm{GPa}$ to $1.8 \AA$ at $16.7 \mathrm{GPa}$. 
Table 3. Crystal data, refinement details, and structure parameters for $\alpha-\mathrm{FeC}_{2} \mathrm{O}_{4} \times 2 \mathrm{H}_{2} \mathrm{O}$ at $p=0.1 \mathrm{GPa}$.

\begin{tabular}{|c|c|c|c|c|c|c|c|c|}
\hline \multicolumn{5}{|c|}{ Chemical Formula } & \multicolumn{4}{|c|}{$\mathrm{FeC}_{2} \mathrm{O}_{4} \times 2 \mathrm{H}_{2} \mathrm{O}$} \\
\hline \multicolumn{5}{|c|}{$M_{\mathrm{r}}$} & \multicolumn{4}{|c|}{719.59} \\
\hline \multirow{2}{*}{\multicolumn{5}{|c|}{$\begin{array}{l}\text { Crystal system, space group } \\
\text { Temperature (K), Pressure (GPa) }\end{array}$}} & \multicolumn{4}{|c|}{ Monoclinic, $C 2 / c$} \\
\hline & & & & & \multicolumn{4}{|c|}{$293,0.1$} \\
\hline \multicolumn{5}{|c|}{$a, b, c(\AA)$} & \multicolumn{4}{|c|}{$11.831(4), 5.5522(1), 9.645(2)$} \\
\hline \multicolumn{5}{|c|}{$\beta\left({ }^{\circ}\right)$} & \multicolumn{4}{|c|}{$126.400(4)$} \\
\hline \multicolumn{5}{|c|}{$V\left(\AA^{3}\right)$} & \multicolumn{4}{|c|}{$509.9(2)$} \\
\hline \multicolumn{5}{|c|}{ Z } & \multicolumn{4}{|c|}{4} \\
\hline \multicolumn{5}{|c|}{ Radiation type } & \multicolumn{4}{|c|}{ Synchrotron, $\lambda=0.41113 \AA$} \\
\hline \multicolumn{5}{|c|}{$\mu\left(\mathrm{mm}^{-1}\right)$} & \multicolumn{4}{|c|}{0.64} \\
\hline \multicolumn{5}{|c|}{ Crystal size $\left(\mathrm{mm}^{3}\right)$} & \multicolumn{4}{|c|}{$0.020 \times 0.020 \times 0.010$} \\
\hline \multicolumn{9}{|c|}{ Data collection } \\
\hline & \multicolumn{4}{|c|}{ ID15B, ESRF } \\
\hline \multicolumn{5}{|c|}{ Absorption correction } & \multicolumn{4}{|c|}{-} \\
\hline \multicolumn{5}{|c|}{$\begin{array}{l}\text { No. of measured, independent and } \\
\text { observed }[I>2.0 \sigma(I)] \text { reflections }\end{array}$} & \multicolumn{4}{|c|}{$878,699,584$} \\
\hline & & $R_{\text {int }}$ & & & & & & \\
\hline & & $\theta / \lambda)_{\max }($ & $-1)$ & & & & & \\
\hline & & & & efinemer & & & & \\
\hline & $R\left[F^{2}\right.$ & $\left.2 \sigma\left(F^{2}\right)\right], w$ & $\left(F^{2}\right), S$ & & & 0.034 & $0,1.03$ & \\
\hline & & of reflect & & & & & & \\
\hline & & of param & ers & & & & & \\
\hline & & of restra & & & & & & \\
\hline & & tom treatn & & & Onl & I-atom c & dinate & ned \\
\hline & $\Delta \rho_{\mathrm{n}}$ & $\Delta \rho_{\min }$ & $\left.\AA^{-3}\right)$ & & & 0.40 & .35 & \\
\hline & & & Struc & ure paras & ers & & & \\
\hline & & $\mathrm{x}$ & $\mathrm{y}$ & $\mathrm{z}$ & Occ & $\mathrm{U}$ & Site & Sym \\
\hline $1 \mathrm{Fe}$ & Fe1 & 0.00000 & 0.07613 & 0.25000 & 1.000 & 0.022 & $4 \mathrm{e}$ & 2 \\
\hline $2 \mathrm{O}$ & $\mathrm{O} 2$ & 0.17640 & 0.06980 & 0.24350 & 1.000 & 0.023 & $8 f$ & 1 \\
\hline $3 \mathrm{H}$ & $\mathrm{H} 22$ & 0.18200 & 0.13900 & 0.17400 & 1.000 & 0.036 & $8 \mathrm{f}$ & 1 \\
\hline $4 \mathrm{H}$ & $\mathrm{H} 21$ & 0.24600 & 0.13000 & 0.33000 & 1.000 & 0.036 & $8 f$ & 1 \\
\hline $5 \mathrm{O}$ & $\mathrm{O} 3$ & 0.41220 & 0.27860 & 0.07710 & 1.000 & 0.024 & $8 \mathrm{f}$ & 1 \\
\hline $6 \mathrm{C}$ & $\mathrm{C} 4$ & 0.45100 & 0.07810 & 0.15090 & 1.000 & 0.014 & $8 f$ & 1 \\
\hline $7 \mathrm{O}$ & O5 & 0.08830 & 0.37610 & 0.42400 & 1.000 & 0.030 & $8 \mathrm{f}$ & 1 \\
\hline
\end{tabular}
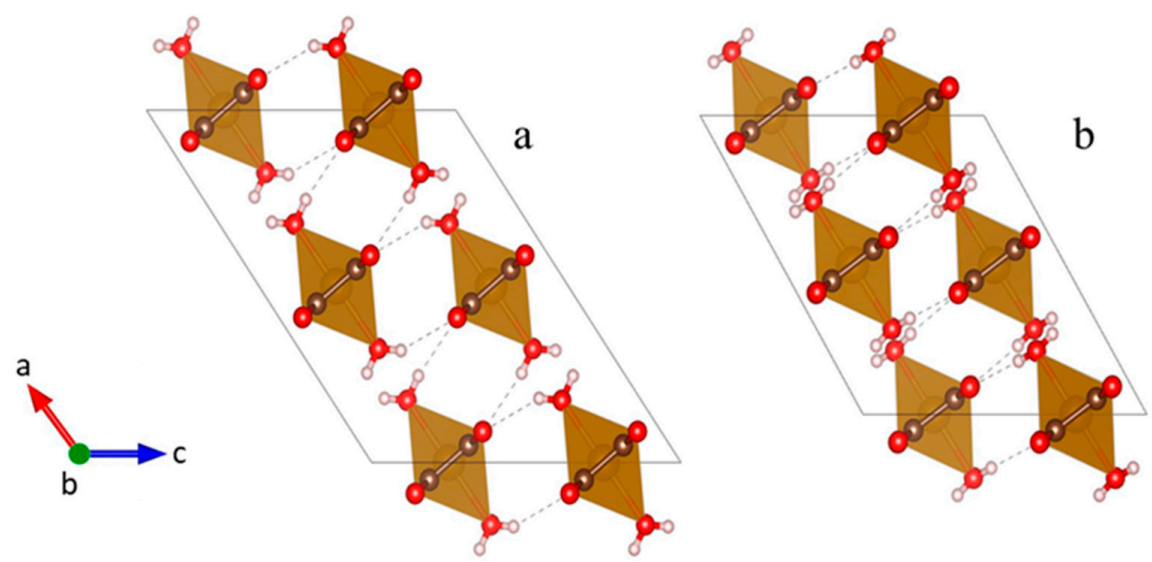

Figure 6. Structural models of iron(II)oxalate dihydrate at $0.1 \mathrm{GPa}(\mathbf{a})$ and $16.7 \mathrm{GPa}$ (b), respectively, viewed along the $b$-axis. Iron atoms are in the center of the brown shaded octahedron, oxygen atoms are shown in red, carbon atoms in brown, and hydrogen atoms in white. Dashed lines indicate the hydrogen bonds. 
Table 4. Crystal data, refinement details, and structure parameters for $\alpha-\mathrm{FeC}_{2} \mathrm{O}_{4} \times 2 \mathrm{H}_{2} \mathrm{O}$ at $p=16.7 \mathrm{GPa}$.

\begin{tabular}{|c|c|c|c|c|c|c|c|c|}
\hline \multicolumn{5}{|c|}{ Chemical formula } & \multicolumn{4}{|c|}{$\mathrm{FeC}_{2} \mathrm{O}_{4} \times 2 \mathrm{H}_{2} \mathrm{O}$} \\
\hline \multicolumn{5}{|c|}{$M_{\mathrm{r}}$} & \multicolumn{4}{|c|}{719.59} \\
\hline \multirow{2}{*}{\multicolumn{5}{|c|}{$\begin{array}{l}\text { Crystal system, space group } \\
\text { Temperature (K) Pressure (GPa) }\end{array}$}} & \multicolumn{4}{|c|}{ Monoclinic, $C 2 / c$} \\
\hline & & & & & & \\
\hline \multicolumn{5}{|c|}{$a, b, c(\AA)$} & \multicolumn{4}{|c|}{$9.360(4), 5.3680(1), 8.6813(18)$} \\
\hline \multicolumn{5}{|c|}{$\beta\left(^{\circ}\right)$} & \multicolumn{4}{|c|}{$122.17(4)$} \\
\hline \multicolumn{5}{|c|}{$V\left(\AA^{3}\right)$} & \multicolumn{4}{|c|}{$369.2(2)$} \\
\hline \multicolumn{5}{|c|}{ Z } & \multicolumn{4}{|c|}{4} \\
\hline \multirow{2}{*}{\multicolumn{5}{|c|}{$\begin{array}{l}\text { Radiation type } \\
\mu\left(\mathrm{mm}^{-1}\right)\end{array}$}} & \multicolumn{4}{|c|}{ Synchrotron, $\lambda=0.41122 \AA$} \\
\hline & & & & & \multicolumn{4}{|c|}{0.88} \\
\hline \multicolumn{5}{|c|}{ Crystal size $\left(\mathrm{mm}^{3}\right)$} & & $0.020 \times 0$ & $\times 0.0$ & \\
\hline \multicolumn{9}{|c|}{ Data collection } \\
\hline & \multicolumn{4}{|c|}{ ID15B, ESRF } \\
\hline \multicolumn{5}{|c|}{ Absorption correction } & \multicolumn{4}{|c|}{ - } \\
\hline \multicolumn{5}{|c|}{$\begin{array}{l}\text { No. of measured, independent and } \\
\text { observed }[I>2.0 \sigma(I)] \text { reflections }\end{array}$} & \multicolumn{4}{|c|}{$657,519,477$} \\
\hline \multicolumn{5}{|c|}{$R_{\text {int }}$} & \multicolumn{4}{|c|}{0.022} \\
\hline & & $\theta / \lambda)_{\max }($ & & & & & & \\
\hline & & & & efinemen & & & & \\
\hline & $R\left[F^{2}\right.$ & $\left.2 \sigma\left(F^{2}\right)\right], w$ & $\left(F^{2}\right), S$ & & & 0.023, & $7,1.03$ & \\
\hline & & of reflect & & & & & & \\
\hline & & of parame & & & & & & \\
\hline & & of restra & & & & & & \\
\hline & & tom treatn & & & Onl & H-atom c & linate & ned \\
\hline & & & Struc & ure paran & ters & & & \\
\hline & & $x$ & $\mathrm{y}$ & $\mathrm{z}$ & Occ. & $\mathrm{U}$ & Site & Sym. \\
\hline $1 \mathrm{Fe}$ & Fe1 & 0.00000 & 0.01820 & 0.25000 & 1.000 & 0.014 & $4 \mathrm{e}$ & 2 \\
\hline $2 \mathrm{O}$ & $\mathrm{O} 2$ & 0.21250 & 0.04330 & 0.23300 & 1.000 & 0.013 & $8 f$ & 1 \\
\hline $3 \mathrm{H}$ & H22 & 0.27000 & 0.12900 & 0.32200 & 1.000 & 0.019 & $8 f$ & 1 \\
\hline $4 \mathrm{H}$ & $\mathrm{H} 21$ & 0.17900 & 0.14600 & 0.15100 & 1.000 & 0.020 & $8 f$ & 1 \\
\hline $5 \mathrm{O}$ & $\mathrm{O} 3$ & 0.40920 & 0.22680 & 0.07230 & 1.000 & 0.016 & $8 \mathrm{f}$ & 1 \\
\hline $6 \mathrm{C}$ & $\mathrm{C} 4$ & 0.44720 & 0.01790 & 0.14710 & 1.000 & 0.013 & $8 f$ & 1 \\
\hline $7 \mathrm{O}$ & O5 & 0.09400 & 0.31340 & 0.43230 & 1.000 & 0.013 & $8 f$ & 1 \\
\hline
\end{tabular}

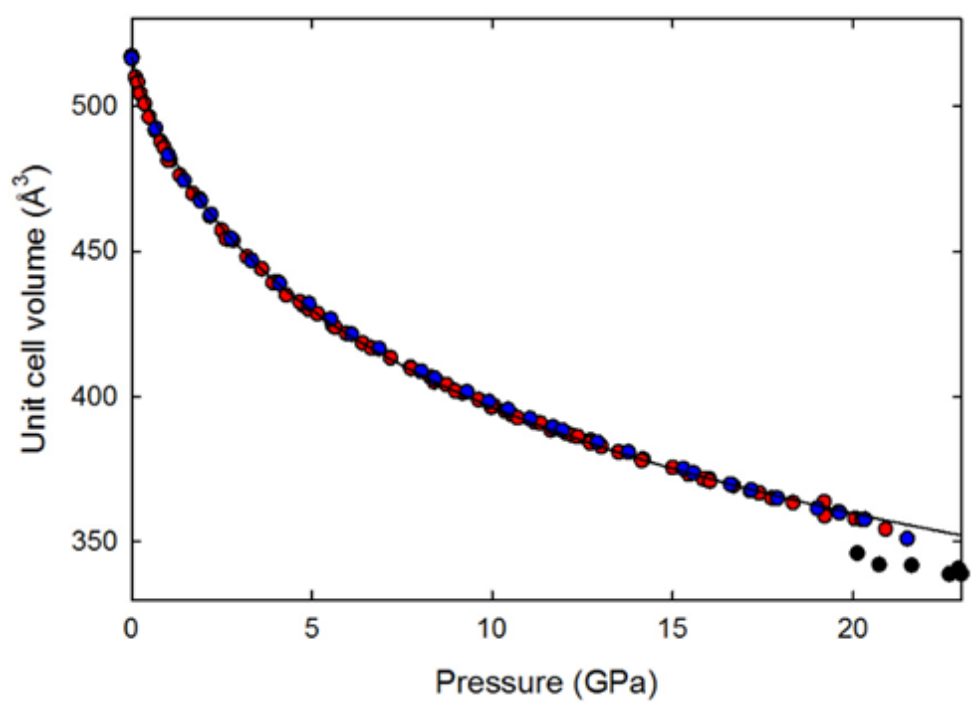

Figure 7. The unit cell volume of protonated $\mathrm{FeC}_{2} \mathrm{O}_{4} \times 2 \mathrm{H}_{2} \mathrm{O}$ (red dots) and its deuterated analogue $\mathrm{FeC}_{2} \mathrm{O}_{4} \times 2 \mathrm{D}_{2} \mathrm{O}$ (blue dots) as a function of pressure. The unit cell volumes of the HP phase at $p \geq 20 \mathrm{GPa}$ are indicated as black dots, the fit of the Vinet EOS to experimental data is shown as black line. 


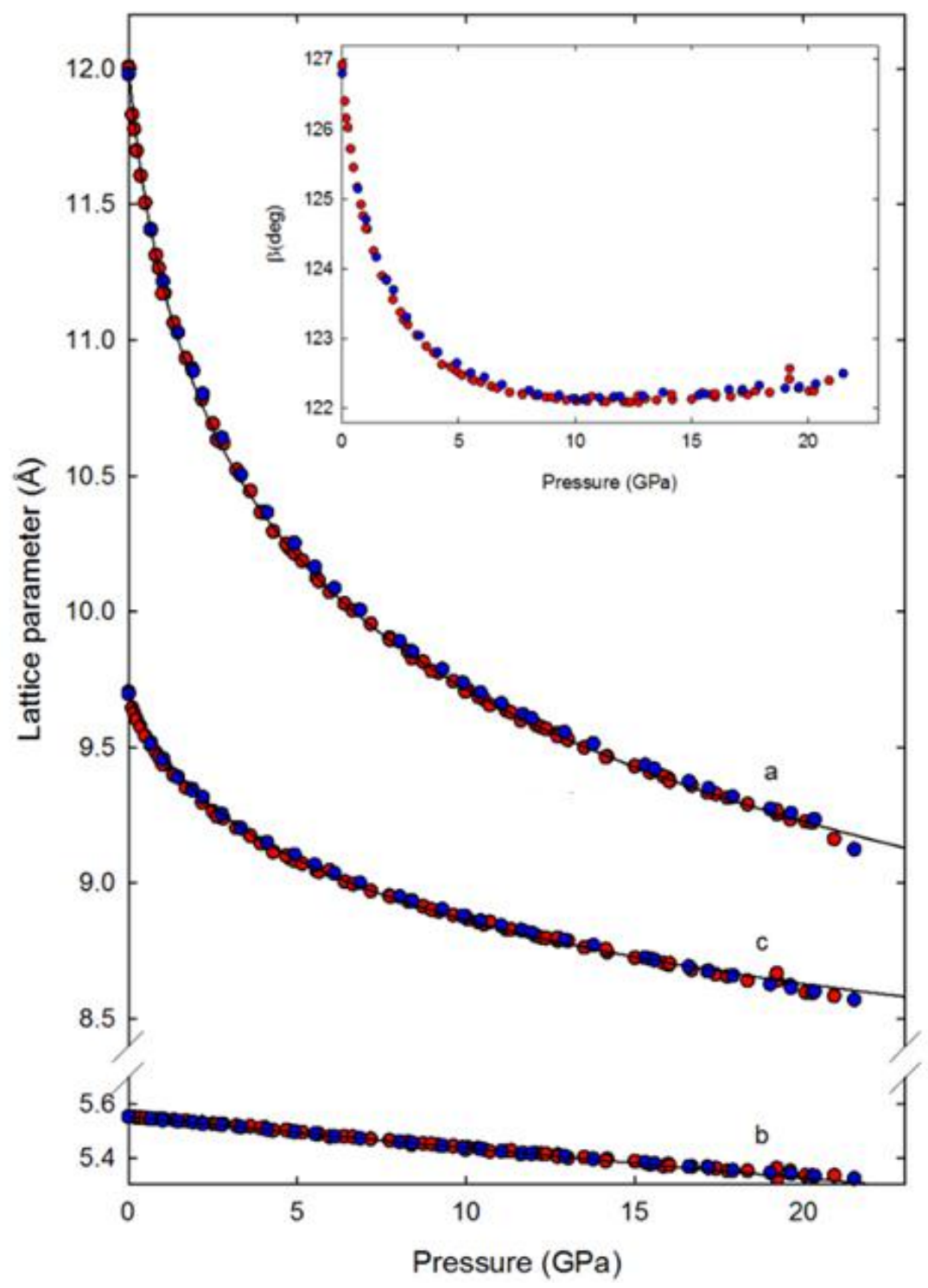

Figure 8. Lattice parameters of $\alpha-\mathrm{FeC}_{2} \mathrm{O}_{4} \times 2 \mathrm{H}_{2} \mathrm{O}$ (red dots) and its deuterated analogue $\alpha$ $\mathrm{FeC}_{2} \mathrm{O}_{4} \times 2 \mathrm{D}_{2} \mathrm{O}$ (blue dots) as a function of pressure. The black lines indicate the fit of the Vinet EOS to experimental data. The insert shows the evolution of the monoclinic angle $\beta$.

Simultaneously, the interactions between neighbouring chains strengthen and the $\mathrm{H}_{2} \mathrm{O}-\mathrm{Fe}-\mathrm{OH}_{2}$ oblique angle decreases as indicated in Figure 6a,b, and Figure 9, respectively

A Vinet equation of state (EOS) was fitted to the measured data with the volume at ambient pressure $\mathrm{V}_{0}$ fixed to the averaged value measured $\left(516.9 \mathrm{~A}^{3}\right)$ [42].

$$
\left.P(V)=3 B_{0}(1-\eta) / \eta^{2}\right) e^{\frac{3}{2}\left(B^{\prime}-1\right)(1-\eta)}, \eta=\sqrt[3]{V / V_{0}}
$$

The bulk modulus $\mathrm{B}_{0}$, its derivative at zero pressure $\mathrm{B}^{\prime}$, and the zero-pressure volume $V_{o}$ of the lattice parameters and of the octahedron volume as obtained from fitting Equation (3) to experimental data are shown in Table 5. 
Table 5. Equation of state parameters for lattice parameters and octahedron. Volume as obtained from Equation (3).

\begin{tabular}{cccc}
\hline & $\mathbf{V}_{\mathbf{0}}$ or $\mathbf{x}_{\mathbf{0}}$ & $\mathbf{B}_{\mathbf{0}}$ or $\mathbf{K}_{\mathbf{0}}$ & $\mathbf{B}^{\prime}$ or $\mathbf{K}^{\prime}$ \\
\hline Unit cell volume & $516.9 \AA^{3}$ (fixed) & $12.42(31) \mathrm{GPa}$ & $8.67(18)$ \\
\hline Octahedron & $12.64(14) \AA^{3}$ & $143(14) \mathrm{GPa}$ & $4.4(2)$ \\
\hline$a$ & $12.005 \AA$ (fixed) & $9.11(25) \mathrm{GPa}$ & $12.81(17)$ \\
\hline$b$ & $5.553 \AA$ (fixed) & $464.3(20) \mathrm{GPa}$ & 1 (fixed) \\
\hline$c$ & $9.700 \AA$ (fixed) & $32.34(74) \mathrm{GPa}$ & $23.44(35)$ \\
\hline
\end{tabular}

The small bulk modulus of $12.4 \mathrm{GPa}$ is typical for a molecular solid the volume change of which is dominated by weak intermolecular interactions. With increasing pressure, these interactions become significantly stronger and result eventually in an unusually high derivative $\mathrm{B}^{\prime}$ of 8.7 , a value considerably higher than anticipated.

The small compression modules $\mathrm{K}_{0}$ for $a$ and $c$ directions indicate that both axes are highly compressible up to $p \approx 10 \mathrm{GPa}$ (Figure 8 ). The intermolecular interactions between 1-D polymer chains increase as a function of applied pressure, as evidenced by the large $\mathrm{K}^{\prime}$ values. The $c$-axis is stiffer than the a-axis because of the alignment of the hydrogen bonds. By contrast, the $b$-axis displays an almost linear pressure dependence $\mathrm{K}_{\mathrm{b}}{ }^{\prime}=1$ and a large compression module $\mathrm{K}_{0 \mathrm{~b}}=464.3 \mathrm{GPa}$.

This observation can be rationalized by recalling the orientation of the planar, infinite ... ox-Fe-ox ... chains along [010]. The planar geometries of the oxalate dianions result from the presence of energetically favorable, delocalized $\pi$-electron systems with charges being spread all over the atoms of the $\mathrm{C}_{2} \mathrm{O}_{4}{ }^{2-}$ backbone. Mesomeric effects together with the "bite angles" of the bidentate ligand result in a relatively rigid atomic arrangement, which in turn gives rise to a large compression module $\mathrm{K}_{0 \mathrm{~b}}=464.3 \mathrm{GPa}$ and an almost linear pressure dependence, $\mathrm{K}_{\mathrm{b}}{ }^{\prime}=1$. The length of the 1-D polymeric chains decreases proportionally to the decrease of the $b$-axis with increasing pressure.

Consequently, the $\mathrm{C}-\mathrm{O}$ bond length of the oxalate anions are only little affected by applied pressure, the value changes from $1.26 \AA$ at $0.1 \mathrm{GPa}$ to $1.245 \AA$ at $16.7 \mathrm{GPa}$.

While structural changes within the chains, dominated by covalent interactions, are generally rather small, the value of the oblique angle $\mathrm{H}_{2} \mathrm{O}-\mathrm{Fe}-\mathrm{OH}_{2}$ decreases continuously from $182^{\circ}$ at ambient pressure to $180^{\circ}$ at $1.7 \mathrm{GPa}$ to $170^{\circ}$ at $20 \mathrm{GPa}$ (Figure 9), just above the phase transition.

The volume of the octahedra decreases from $12.6 \AA^{3}$ at ambient pressure with increasing pressure to $11.3 \AA^{3}$ at $20 \mathrm{GPa}$ (Figure 10), a value that is small and corresponds to less than $1 \%$ of the change of the unit cell volume. The corresponding bulk modulus and its derivative amount to $143 \mathrm{GPa}$ and 4.4, respectively, values typical for a molecule crystal with weak intermolecular interactions.

A measure for the distortion of an octahedron is the distortion index as expressed in Equation (4).

$$
D=\frac{1}{n} \sum_{i=1}^{n} \frac{\left|l_{i}-l_{a v}\right|}{l_{a v}}
$$

$l_{i}$ is the distance from the central atom Fe to the ith coordinating atom, and $l_{a v}$ is the average bond length. D remains constant to about $10 \mathrm{GPa}$ and increases slightly above (inset, Figure 10)

Anisotropic changes of lattice parameters and other physical properties are very common in molecular materials and originate from variable packing motifs and differing strengths of intermolecular interactions along different unit cell axes [43]. 


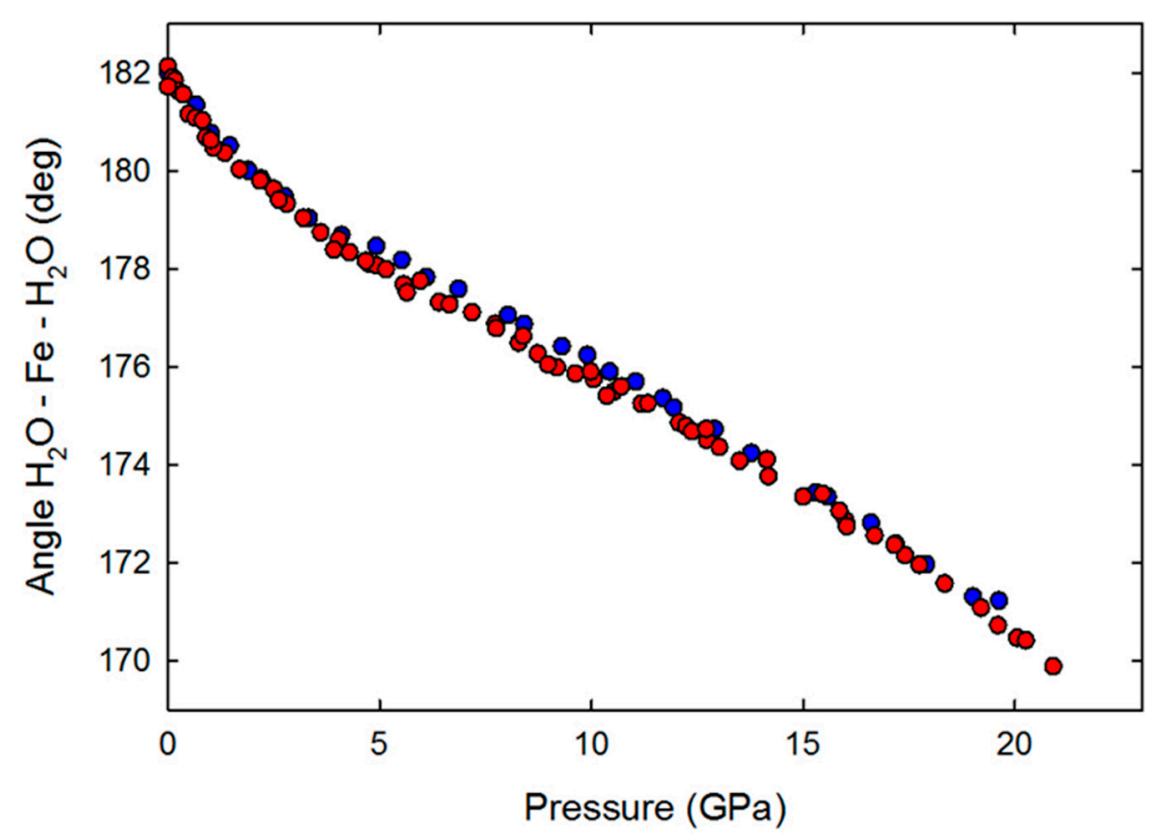

Figure 9. Oblique angle $\mathrm{H}_{2} \mathrm{O}-\mathrm{Fe}-\mathrm{OH}_{2}$ between the oxygen atoms of axial water molecules and the central iron atom of $\alpha-\mathrm{FeC}_{2} \mathrm{O}_{4} \times 2 \mathrm{H}_{2} \mathrm{O}$ (red dots) and its deuterated analogue $\alpha-\mathrm{FeC}_{2} \mathrm{O}_{4} \times 2 \mathrm{D}_{2} \mathrm{O}$ (blue dots) as a function of pressure.

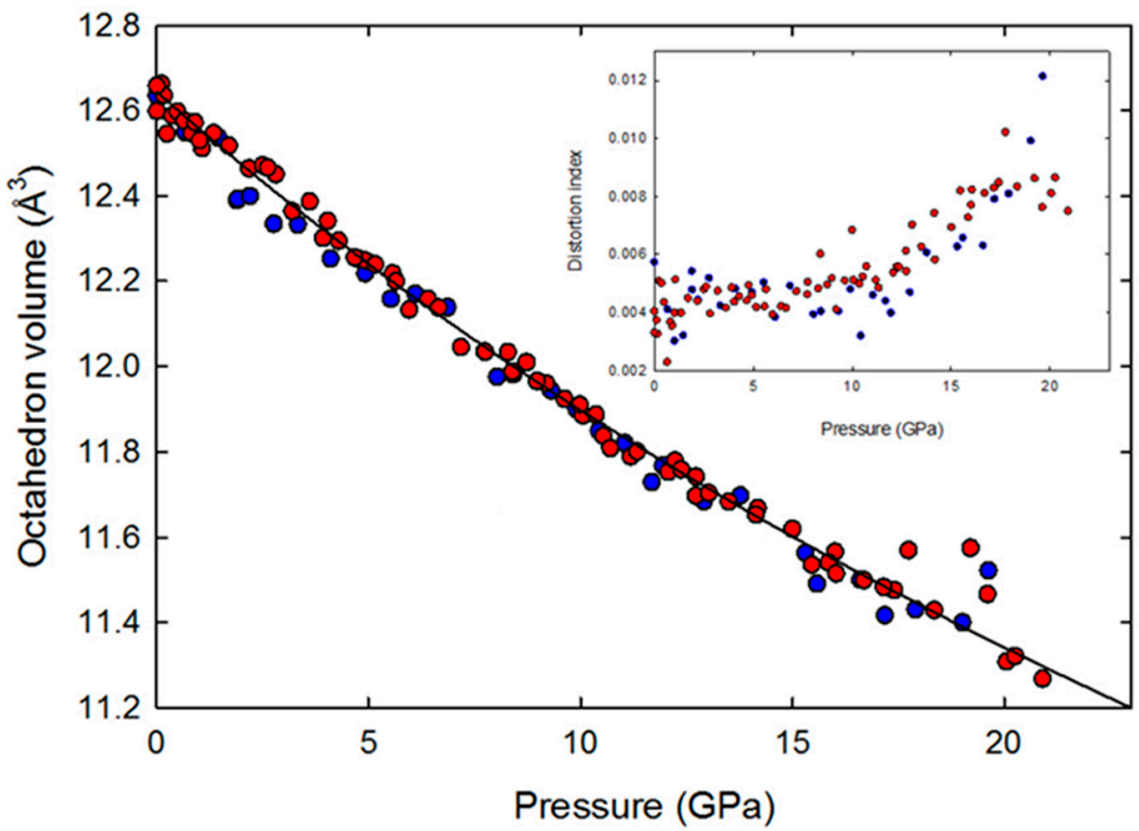

Figure 10. Octahedron volume of iron(II)oxalate dihydrate (red dots) and its deuterated analogue $\mathrm{FeC}_{2} \mathrm{O}_{4} \times 2 \mathrm{D}_{2} \mathrm{O}$ (blue dots) as a function of applied pressure. The black line denotes the fit of the Vinet EOS to experimental data. The insert shows the distortion index D.

\section{Discussion}

The two-step preparative protocol to $\alpha-\mathrm{FeC}_{2} \mathrm{O}_{4} \times 2 \mathrm{H}_{2} \mathrm{O}$ and other, isotopically labeled analogues such as $\alpha-\mathrm{FeC}_{2} \mathrm{O}_{4} \times 2 \mathrm{D}_{2} \mathrm{O}$ and $\alpha-{ }^{57} \mathrm{FeC}_{2} \mathrm{O}_{4} \times 2 \mathrm{H}_{2} \mathrm{O}$ reported here, opens up an operationally simple and versatile procedure to high-quality single crystals of synthetic phase-pure products for X-ray and neutron diffraction, ${ }^{57} \mathrm{Fe}$ Mößbauer spectroscopy, as well as for high pressure research [44]. 
As the approach starts from readily available elemental iron, no constraints or limitations arising from non-commercial precursors are to be expected. The procedure can easily be adapted to other transition metal oxalates or salts [29].

All synthetic operations have been carried out in inert atmosphere using appropriate Schlenk techniques to avoid any possible contamination provoked by the ubiquitous presence of atmospheric oxygen $[9,10]$.

The preparative protocol given above provides selectively phase-pure $\alpha-\mathrm{FeC}_{2} \mathrm{O}_{4} \times 2 \mathrm{H}_{2} \mathrm{O}$ and $\alpha-\mathrm{FeC}_{2} \mathrm{O}_{4} \times 2 \mathrm{D}_{2} \mathrm{O}$, respectively.

The propensity of $\mathrm{FeC}_{2} \mathrm{O}_{4} \times 2 \mathrm{H}_{2} \mathrm{O}$ to produce solids with stacking faults upon crystallization has been investigated in detail [14-17].

Naturally occurring humboldtine or its isomorphous, synthetic equivalent $\alpha-\mathrm{FeC}_{2} \mathrm{O}_{4} \times 2 \mathrm{H}_{2} \mathrm{O}$ is the thermodynamically stable polymorph. This phase crystallizes in the monoclinic space group $\mathrm{C} 12 / \mathrm{c} 1$, whereas disordered $\beta-\mathrm{FeC}_{2} \mathrm{O}_{4} \times 2 \mathrm{H}_{2} \mathrm{O}$ crystallizes in the orthorhombic lattice $\mathrm{Cccm}$.

When employing suitable conditions, the stacking faults of $\beta-\mathrm{FeC}_{2} \mathrm{O}_{4} \times 2 \mathrm{H}_{2} \mathrm{O}$ can be healed, and the substance transforms irreversibly in a solid state reaction into $\alpha-\mathrm{FeC}_{2} \mathrm{O}_{4} \times 2 \mathrm{H}_{2} \mathrm{O}$ [14].

The synthesis of nanoparticles of $\beta-\mathrm{FeC}_{2} \mathrm{O}_{4} \times 2 \mathrm{H}_{2} \mathrm{O}$ was achieved by a mechanochemical procedure, the product of which displays photocatalytic properties [9]. $\beta$ - $\mathrm{FeC}_{2} \mathrm{O}_{4} \times 2 \mathrm{H}_{2} \mathrm{O}$ and mixtures of $\alpha$ - and $\beta-\mathrm{FeC}_{2} \mathrm{O}_{4} \times 2 \mathrm{H}_{2} \mathrm{O}$ were prepared by a micellar approach or a solvothermal synthesis, respectively $[10,11]$. The latter products were transformed by annealing into anhydrous $\mathrm{FeC}_{2} \mathrm{O}_{4}$, an amorphous solid of unknown structure, employed as electrode material.

The spectroscopic properties of $\alpha-\mathrm{FeC}_{2} \mathrm{O}_{4} \times 2 \mathrm{H}_{2} \mathrm{O}$ obtained correspond to those described in previous work $[9,19,36]$. FT-IR data obtained on $\alpha-\mathrm{FeC}_{2} \mathrm{O}_{4} \times 2 \mathrm{D}_{2} \mathrm{O}$ show the expected shifts and confirm a quantitative exchange of $\mathrm{H}$ against $\mathrm{D}$.

The crystal and molecular structure of the mineral humboldtine, $\mathrm{FeC}_{2} \mathrm{O}_{4} \times 2 \mathrm{H}_{2} \mathrm{O}$ at ambient conditions was described for the first time in 1957 [12]. The sample used was co-type material from the isle of Elba (Italy) [45]. Improved structural models obtained by $\mathrm{X}$-ray and neutron diffraction studies were reported in later work [13-18].

The lattice parameters and atomic positions of $\alpha-\mathrm{FeC}_{2} \mathrm{O}_{4} \times 2 \mathrm{H}_{2} \mathrm{O}$ reported here are in excellent agreement with the results of a previous single crystal study [19]. No isotopic effect has been observed upon $\mathrm{H} / \mathrm{D}$ exchange. The cell parameters of $\alpha-\mathrm{FeC}_{2} \mathrm{O}_{4} \times 2 \mathrm{H}_{2} \mathrm{O}$ and $\alpha-\mathrm{FeC}_{2} \mathrm{O}_{4} \times 2 \mathrm{D}_{2} \mathrm{O}$ are indistinguishable.

The oxalate dianion is a conjugated, extended, planar $\pi$-system, capable to act as a bidentate ligand, and thus to form coordination polymers with suitable metal cations. Despite being formally a salt, the title compound should not be viewed as an ionic compound composed of oxalate anions and iron(II)cations with strong attractive, electrostatic forces, but rather as a typical molecular solid. The valence electrons of humboldtine are localized in defined molecular orbitals disabling intermolecular electron transfer, which makes the compound a poor electrical conductor and accounts for the yellow aspect of the solid $[8,10,11]$.

Planar polymeric iron oxalate chains form through coordinate covalent bonds between ligand and central metal and represent the conformationally, relatively rigid backbone of the molecular and crystal structure. Individual chains are held together essentially through hydrogen bonds. Water molecules at the axial positions complete the octahedral coordination sphere of iron(II)cations and act as molecular linkers between neighboring chains. The infinite ... oxFeoxFeox ... chains of humboldtine are arranged in stacks along $a$ with perpendicular coordinated water molecules and little, if any intrastack interactions. Each water molecule forms hydrogen bonds to neighboring oxalate ligands, a feature characteristic of the title compound and isostructural oxalates [14].

Hence, both strong covalent intramolecular interactions, as realized in the polymeric backbone, and weaker-than-covalent intermolecular forces as represented by hydrogen bonds, exist in the humboldtine crystal. 
A similar hierarchy of intra- and intermolecular forces is found also in molecular solids composed of charged constituents, such as charge-transfer (CT) complexes and radical salts [46].

Generally, these compounds comprise essentially planar, $\pi$-conjugated electron donor and acceptor molecules arranged in separate stacks or layers with only weak intrastack or intralayer interactions. Contrary to the title compound, the presence of unpaired, delocalized valence electrons enables intermolecular charge transfer and electronic conduction. These solids usually exhibit layered structures, which results in anisotropic physico-chemical properties. The pressure dependence of the structural properties of single crystals of $\mathrm{FeC}_{2} \mathrm{O}_{4} \times 2 \mathrm{H}_{2} \mathrm{O}$ and its deuterated analogue further corroborates an interpretation of humboldtine as molecular solid.

The compound can be compressed reversibly up to $p=20 \mathrm{GPa}$ without any major structural transition, despite a reduction of the unit cell volume by about $50 \%$. The compressibility along $b$ is low, while this parameter is highest along $a$, the stacking direction of the oxalate chains.

In view of the orientation of the stiff polymer chains along [010] and the more flexible stacking axis along $a$, this result is not surprising and reflects the pronounced anisotropy of the molecular edifice of humboldtine. The water molecules act as flexible joints of the molecular architecture, as evidenced by the decrease of the almost linear, axial $\mathrm{H}_{2} \mathrm{O}-\mathrm{Fe}-\mathrm{OH}_{2}$ angle at ambient $\mathrm{p}$ to a value of about $170^{\circ}$ at $20 \mathrm{GPa}$ and constitute an essential element of the crystal structure of the title compound.

As Lewis acid or electron pair acceptor, the iron(II)cation is capable of polarizing the axial water ligands in such a way that dissociation can occur, and protons become mobile.

The amazingly high proton conductivity of $\mathrm{FeC}_{2} \mathrm{O}_{4} \times 2 \mathrm{H}_{2} \mathrm{O}$ has been rationalized following this line of reasoning [8]. Pressure-induced changes of $\mathrm{Fe}-\mathrm{O}$ bond distances and

$\mathrm{H}_{2} \mathrm{O}-\mathrm{Fe}-\mathrm{OH}_{2}$ angles are likely to affect the strength of the $\mathrm{O}-\mathrm{H}$ bond and thus the proton mobility. As outlined above, the geometry of the oxalate dianions is not much affected by applied hydrostatic pressure. By contrast, the Fe-O distance of the axial water molecules decreases from $2.2 \AA(p=0)$ to $2.08 \AA(p=16.7 \mathrm{GPa})$ and the $\mathrm{H}_{2} \mathrm{O}-\mathrm{Fe}-\mathrm{OH}_{2}$ oblique angle shrinks from $180^{\circ}(p=0)$ to $173^{\circ}$ at $16.7 \mathrm{GPa}$. In the same pressure interval, $\mathrm{H} \ldots$ $\mathrm{O}$ contacts between adjacent polymer chains shorten from $2.0 \AA$ to $1.8 \AA$. The observed shortening of the Fe-O distances translates into a strengthening of these bonds, which may result in additional polarization and weakening of the $\mathrm{O}-\mathrm{H}$ bonds. This effect could be amplified possibly by the simultaneous decrease of both intermolecular hydrogen bonds and $\mathrm{H}_{2} \mathrm{O}-\mathrm{Fe}-\mathrm{OH}_{2}$ angles (Figure 9), respectively, and cause a considerable rise in proton conductivity. In the absence of any experimental data and in view of the complex interplay of intra- and intermolecular interactions, any predictions on the pressure dependence of the proton conductivity remain speculative.

The elucidation of the crystal structure of the HP phase, which forms at $p \geq 20 \mathrm{GPa}$ as a consequence of a structural phase transition, shall be an experimental challenge for future work. An extension of the present study to higher temperatures and possibly pressures shall provide interesting insights into the properties of anhydrous $\mathrm{FeC}_{2} \mathrm{O}_{4}$ and other transient phases formed during the transformation of humboldtine into siderite $\mathrm{FeCO}_{3}$.

Author Contributions: Preparative work and analytical characterizations, L.B. and H.M.; S-XRD experiments and data analysis, M.H.; writing—original draft preparation, H.M. All authors have read and agreed to the published version of the manuscript.

Funding: This research has been funded by the ESRF.

Acknowledgments: The authors thank I. Snigireva, ESRF for taking the SEM image.

Conflicts of Interest: The authors declare no conflict of interest. 


\section{References}

1. De Rivero, M. Note sur une combinaison de l'acide oxalique avec le fer trouvé a Kolowserux, prés Belin, Bohêmia. Ann. Chim. Phys. 1821, 18, 207-210.

2. Baran, J.E. Natural iron oxalates and their synthetic counterparts: A review. Chem. Erde Geochem. 2016, 76, 449-460. [CrossRef]

3. Vigouroux, D.; Auffredic, J.-P.; Carel, C.; Vallet, P. Contribution à l'étude de la pyrolyse de l'oxalate ferreux dihydraté. C.R. Acad. Sc. Paris 1966, 263, 177-180.

4. Brown, R.A.; Bevan, S.C. The thermal decomposition of Ferrous Oxalate Dihydrate. J. Inorg. Nucl. Chem. 1966, $28,387-391$. [CrossRef]

5. Rane, K.S.; Nikumbh, K.A.; Mukedkja, A.J. Thermal decomposition of ferrous oxalate dihydrate studied by current electrical conductivity measurements. J. Mater. Sci. 1981, 16, 2387-2397. [CrossRef]

6. Sayed, F.N.; Polshettiwar, V. Facile and sustainable synthesis of shaped iron particles: Effect of iron precursor salt on the shapes of iron oxides. Sci. Rep. 2015, 5, 9733. [CrossRef]

7. Kopp, J.; Novak, P.; Kaslik, J.; Pechousek, J. Preparation of magnetite by thermally induced decomposition of ferrous oxalate dihydrate in the combined atmosphere. Acta Chim. Slov. 2019, 66, 455-465. [CrossRef]

8. Yamada, T.; Sadakiyo, M.; Kitagawa, H. High proton conductivity of one-dimensional ferrous oxalate dihydrate. J. Am. Chem. Soc. 2009, 131, 3144-3145. [CrossRef]

9. Liu, Z.-J.; Liu, W.; Wang, Y.; Guo, M.-L. Preparation of $\beta$-ferrous oxalate dehydrate layered nano sheets by mechanochemical method and its visible light-driven photocatalytic performance. Mat. Lett. 2016, 178, 83-86. [CrossRef]

10. Aragón, M.J.; León, B.; Vicente Pérez, C.; Tirado, J.L. Synthesis and Electrochemical Reaction with Lithium of Mesoporous Iron Oxalate Nanoribbons. Inorg. Chem. 2008, 47, 10366-10371.

11. Zhang, K.; Li, Y.; Wang, Y.; Zhao, J.; Chen, X.; Dai, Y.; Yao, Y. Enhanced electrochemical properties of iron oxalate with more stable $\mathrm{Li}^{+}$ions diffusion channels by controlling polymorphic structure. Chem. Eng. J. 2020, 384, 123281. [CrossRef]

12. Mazzi, F.; Garavelli, C. La struttura della oxalate: $\mathrm{FeC}_{2} \mathrm{O}_{4} 2 \mathrm{H}_{2} \mathrm{O}$. Per. Miner. 1957, 26, 269-303.

13. Carić, S. Amélioration de la structure de la humboldtine $\mathrm{FeC}_{2} \mathrm{O}_{4} 2 \mathrm{H}_{2} \mathrm{O}$. Bull. Soc. Franç. Minér. Crist. 1959, 82, 50-56.

14. Lagier, J.P.; Pezerat, H. Études des phases obtenues lors de la préparation d'oxalates de métaux de transition. C. R. Hebd. Seances L Acad. Sci. Ser. C 1967, 264, 496-498.

15. Lagier, J.P.; Pezerat, H.; Dubernat, J. Oxalates dihydratés de Mg, Mn, Fe, Co, Ni et Zn divalents: Évolution vers la forme la plus ordonnée de composes présentant des fautes d'empilement. Rev. Chim. Min. 1969, 6, 1081-1092.

16. Deyrieux, R.; Peneloux, A. Contribution à l'étude des oxalates de certains métaux bivalents—Structure crystalline des deux forms allotropiques de l'oxalate ferreux dihydraté. Bull. Soc. Chem. Fr. 1969, 8, 2675-2680.

17. Dubernat, J.; Pezerat, H. Fautes d’Empilement dans les Oxalates Dihydratés des Métaux Divalents de la Série Magnésienne (Mg, Fe, Co, Ni, Zn, Mn). J. Appl. Cryst. 1974, 7, 387-393. [CrossRef]

18. Śledzińska, I.; Murasik, A.; Piotrowski, M. Neutron diffraction study of crystal and magnetic structures of $\alpha$-FeC2O4 2D2O. Phys. B Condens. Matter 1986, 138B, 315-322.

19. Echigo, T.; Kimata, M. Single crystal X-ray diffraction and spectroscopic studies on humboldtine and lindbergite: Weak Jahn-Teller effect of $\mathrm{Fe}^{2+}$-ion. Phys. Chem. Min. 2008, 35, 467-475. [CrossRef]

20. French, B.M. Stability relations of siderite $\left(\mathrm{FeCO}_{3}\right)$ in the system Fe-C-O. Am. J. Sci. 1971, 271, 37-78. [CrossRef]

21. Cerantolo, V.; McCammon, C.; Kupenko, I.; Kantor, I.; Marini, C.; Wilke, M.; Ismailova, L.; Solopova, N.; Chumakov, A.; Pascarelli, S.; et al. High pressure spectroscopic study of siderite $\left(\mathrm{FeCO}_{3}\right)$ with a focus on spin crossover. Am. Min. 2015, 100, $2670-2681$. [CrossRef]

22. Liang, W.; Chen, L.; Wang, L.; Yin, Z.; Li, Z.; Li, H. High pressure synthesis of siderite $\left(\mathrm{FeCO}_{3}\right)$ and its thermal expansion coefficient. High. Temp. High. Press. 2018, 47, 153-164.

23. Boulard, E.; Menguy, N.; Auzende, A.L.; Benzerara., K.; Bureau, H.; Antonageli, D.; Corgne, A.; Morard, G.; Siebert, J.; Perillat, J.P.; et al. Experimental investigation of the stability of Fe-rich carbonates in the lower mantle. J. Geophys. Res. 2012, 117, BO2208. [CrossRef]

24. Cerantolo, V.; Bykova, E.; Kupenko, I.; Merlini, M.; Ismailova, L.; McCammon, C.; Bykov, M.; Chumakov, A.; Petitgirard, S.; Kantor, I.; et al. Stability of iron-bearing carbonates in the deep earth's interior. Nat. Comm. 2017, 8, 15960. [CrossRef]

25. Rosenberg, P.E. Synthetic solid solutions in the systems $\mathrm{MgCO}_{3}-\mathrm{FeCO}_{3}$ and $\mathrm{MnCO}_{3}-\mathrm{FeCO}_{3}$. Am. Min. 1963, 48, 1396-1400.

26. Romanek, C.S.; Jiménez-López, C.; Rodriguez Navarro, A.; Sáchez-Román, M.; Sahai, N.; Coleman, M. Inorganic synthesis of Fe-Ca-Mg carbonates at low temperature. Geochim. Cosmochim. Acta. 2009, 73, 5361-5376. [CrossRef]

27. Merlini, M.; Hanfland, M.; Salamat, A.; Petitgirard, S.; Müller, H. The crystal structures of $\mathrm{Mg}_{2} \mathrm{Fe}_{2} \mathrm{C}_{4} \mathrm{O}_{13}$ with tetrahedrally coordinated carbon, and $\mathrm{Fe}_{13} \mathrm{O}_{19}$, synthesized at deep mantle conditions. Am. Min. 2015, 100, 2001-2004. [CrossRef]

28. Packter, A. The precipitation of transition metal oxalate powders from aqueous solution. Crystal numbers and final sizes. Krist. Tech. 1976, 11, 1131-1138. [CrossRef]

29. Rhoda, R.N.; Fraili, A.V.; Taylor, W.L.; Kleinberg, J. Inorganic Syntheses; McGraw Hill Book Company Inc.: New York, NY, USA, 1953; pp. 159-161.

30. Mao, H.K.; Xu, J.; Bell, P.M. Calibration of the ruby pressure gauge to 800 kbar under quasi-hydrostatic conditions. J. Geophys. Res. 1986, 91, 4673-4676. [CrossRef] 
31. Merlini, M.; Hanfland, M. Single-crystal diffraction at megabar conditions by synchrotron radiation. High Press. Res. 2013, 3, 511-522. [CrossRef]

32. Rigaku Oxford Diffraction. CrysAlisPro Software System; Version 1.171.38.46; Rigaku Corporation: Oxford, UK, 2018.

33. Betteridge, P.W.; Carruthers, J.R.; Cooper, R.I.; Prout, K.; Watkin, D.J. CRYSTALS, Version 12: Software for guided crystal structure analysis. J. Appl. Cryst. 2003, 36, 1487. [CrossRef]

34. Momma, K.; Izumi, F. VESTA 3 for three-dimensional visualization of crystal, volumetric and morphology data. J. Appl. Cryst. 2011, 44, 1272-1276. [CrossRef]

35. Gonzalez-Platas, J.; Alvaro, M.; Nestola, F.; Angel, R. EosFit7-GUI: A new GUI tool for equation of state calculations, analyses, and teaching. J. Appl. Cryst. 2016, 49, 1377-1382. [CrossRef]

36. D'Antonio, M.C.; Wladimirsky, A.; Palicios, D.; Coggiola, L.; González-Baró, A.C.; Baran, E.J.; Mercader, R.C. Spectroscopic Investigations of Iron(II) and Iron(III) Oxalates. J. Braz. Chem. Soc. 2009, 20, 445-450. [CrossRef]

37. Gaffey, S.J. Spectral reflectance of carbonate minerals in the visible and near infrared (0.35-2.55 $\mu \mathrm{m})$ : Anhydrous carbonate minerals. J. Geophys. Res. 1987, 92, 1429-1440. [CrossRef]

38. Applin, M.D.; Izawa, M.R.M.; Cloutis, E.A. Reflectance spectroscopy of oxalate minerals and relevance to solar system carbonate inventories. Icarus 2016, 278, 7-30. [CrossRef]

39. Ito, K.; Bernstein, H.J. The vibrational spectra of the formate, acetate and oxalate ions. Can. J. Chem. 1956, 34, 170-178. [CrossRef]

40. Nakamoto, K. Infrared and Raman Spectra of Inorganic and Coordination Compounds, 5th ed.; Wiley: New York, NY, USA, 1997.

41. Frost, R.L.; Yang, J.; Ding, Z. Raman and FTIR spectroscopy of natural oxalates: Implications for the evidence of life on Mars. Chin. Sci. Bull. 2003, 48, 1844-1852. [CrossRef]

42. Vinet, P.; Smith, J.R.; Ferrante, J.; Rose, J.H. Temperature effects on the universal equation of state of solids. Phys. Rev. B 1987, 35, 1945-1953. [CrossRef]

43. Collings, I.E.; Hanfland, M. Packing Rearrangements in 4-Hydroxycyanobenzene under pressure. Molecules 2019, $24,1759$. [CrossRef]

44. Manasse, E. Oxalite from Cape D'Arco (Elba). Rend. Accad. Lincei. 1911, 19, 138-145.

45. Cerantolo, V. European XFEL GmbH, Hamburg, Germany. Personal Communication, 15 September 2020. First 57 Fe Mößbauer spectroscopy measurements using single crystals of ${ }^{57} \mathrm{FeC}_{2} \mathrm{O}_{4} \times 2 \mathrm{H}_{2} \mathrm{O}$ at ambient and elevated pressures were carried out successfully at the Nuclear Resonance Beamline ID 18 of the ESRF.

46. Schwoerer, M.; Wolf, H.C. Organic Molecular Solids, 1st ed.; Wiley-VCH: Berlin, Germany, 2006. 